\title{
Selecting Criteria for Assessing "Environmentally-Friendly" Material Options in Construction: Part I
}

\author{
Robert Bucoń $^{1}$ and Agata Czarnigowska ${ }^{2}$ \\ ${ }^{1}$ Dpt. Of Construction Methods and Management, Faculty of Civil Engineering and Architecture, \\ Politechnika Lubelska, Nadbystrzycka 40,20-618 Lublin, Poland, r.bucon@pollub.pl \\ ${ }^{2}$ Dpt. Of Construction Methods and Management, Faculty of Civil Engineering and Architecture, \\ Politechnika Lubelska, Nadbystrzycka 40, 20-618 Lublin, Poland, a.czarnigowska@pollub.pl
}

\begin{abstract}
One of the design team's tasks is assuring that their project has a low negative impact on the environment. This comes from regulations as well as expectations of direct benefits (reduction of operating cost, the project's improved image in the eyes of the public, etc.). To fulfill this task, one needs to define criteria for assessing the design options. These are to correspond to the individual qualities of the project, and they should be significant and possible to assess. The paper, divided into two parts, presents a review of the literature concerning the criteria for the assessment of design solutions defined as "green" or "environmentally friendly". Part I presents the method of the analysis and investigates into the number and type of criteria adopted in the sample of papers being the object of analysis. Part II focuses on the ways of defining criteria values, weights, and methods of multicriteria assessment.
\end{abstract}

Keywords: Sustainable Construction, Component Selection, LCA, Literature Review.

\section{Introduction}

It becomes apparent that humanity's appetite for resources became too much for the planet Earth to bear (Meadows et al., 1972; Turner, 2008). Exponential population build-up combined with the global pursuit of economic growth results in the exponential growth of the demand for housing and infrastructure as well as production facilities. Construction means consuming a lot of energy, water, land, and minerals for creating millions of tons of materials, moving them to the destination and installing, followed by dismantling and relocating with the amount of effort comparable with that during erection. Technological progress makes construction components increasingly complex and sophisticated, which adds to the problem: highly processed products consume even more resources and are difficult to recycle. In the face of resource depletion and the likely suffocation with its own refuse within decades, humanity is dragged (Komatsu et al., 2019) towards the sustainable economy (D'Amato et al., 2019) and, in particular, sustainable construction (Goh et al., 2020).

One of the aspects of construction sustainability is reducing the project's and the resulting built facility's negative impact on the environment. This impact is typically assessed in the course of some form of Life Cycle Analysis (LCA) (Ortiz et al., 2009). The LCA has become an established practice in optimizing designs and assessing the quality of the built environment. The idea, described among others by ISO 14040 standard, evolved into a plethora of methodologies, tools and individual reports on analyses for estimating the impact of built assets on the environment from the perspective of:

- particular construction materials/products (e.g. Häfliger et al., 2017),

- functional components of particular buildings (e.g. Kellenberger and Althaus, 2009), 
- whole buildings in the context of the way of use and building maintenance scenarios (Bucoń, 2019; Häfliger et al., 2017; Hasik et al., 2019),

- neighborhoods/cities (Bak et al., 2019; Goldstein et al., 2013; Jeong and RamirezGomez, 2018; Nematchoua et al., 2020).

They typically share the element of assessing the environmental consequences of using particular construction materials in the building's fabric, so the materials' contribution to the overall environmental impact. However, even in this narrow aspect, the scope, criteria, and measures used in the analyses are not identical (Doan et al., 2017; Park et al., 2017).

On the one hand, there exist standards on reporting the environmental impact of products, (ecolabelling). As for the construction products, the European EN 15804 standard that sets requirements for voluntary Environmental Product Declarations (EPDs) (Kuittinen and Linkosalmi, 2015; Piasecki, 2014). On the other hand, the standards and methodologies evolve (Allacker et al., 2017). Due to the proliferation of LCA methodologies, the comparability of information on a product's environmental qualities becomes an issue (European Commission, 2013; Galatola and Pant, 2014; Passer et al., 2015). Many researchers and practitioners compare the environmental qualities of construction products using their own criteria and measures.

The paper is the first part of a review of the most recent literature on the comparison or assessment of construction products and components to select the "environmentally friendly" ones. The authors provide a classification of research problems covered by the sample, discuss papers devoted to designing "green" materials and selecting sustainability criteria for construction materials, products, or components. Finally, they investigate into the number and type of criteria in us construction products

2 Materials and
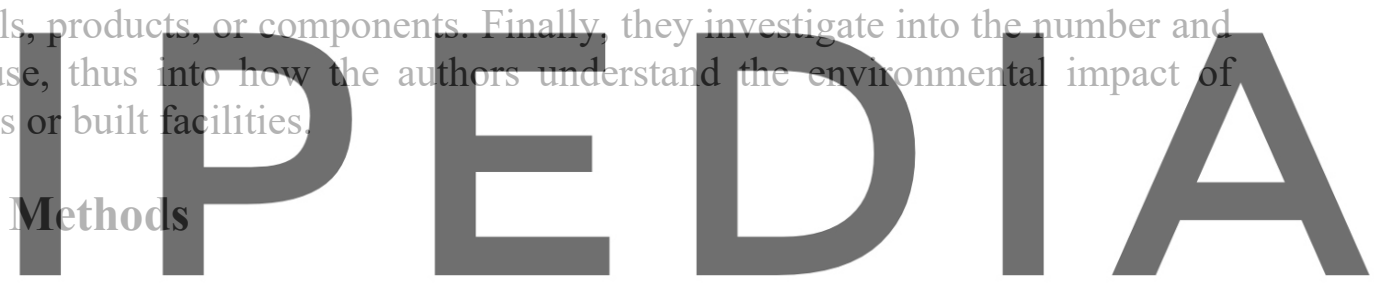

2.1 Benchmark Set of Criteria and the Scope of Analysis

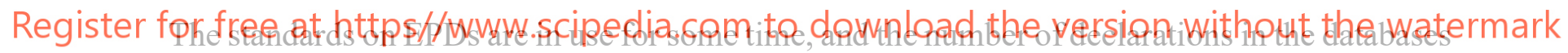

is growing: this idea of standardized communication of environmental product properties seems

to establish itself in practice. For this reason, the authors expect that the presentation of solutions to problems directly or indirectly related to construction material, component, or construction method selection in the field of architecture, building, and civil engineering are likely to draw from the methods elaborated by the environmental scientists.

Table 1. Classification of life cycle stages for assessing environmental impact of construction products, based on EPD (ITB, 2013).

\begin{tabular}{lllll}
\hline \multicolumn{1}{c}{ Product stage } & $\begin{array}{c}\text { Construction } \\
\text { process }\end{array}$ & \multicolumn{1}{c}{ Use stage } & End of life & $\begin{array}{c}\text { Benefits and loads } \\
\text { beyond the system } \\
\text { boundary }\end{array}$ \\
\hline A1. Raw material & A4. Trans- & B1. Use & C1. Decon- & D. Reuse- \\
supply & port to site & B2. Maintenance & struction & recovery- \\
A2. Transport & A5. Instal- & B3. Repair & C2. Transport & recycling \\
A3. & lation & B4. Replacement & C3. Waste & potential \\
Manufacturing & & B5. Refurbishment & processing & \\
& & B6. Operational energy use & C4. Disposal & \\
& & B7. Operational water use & & \\
\hline
\end{tabular}


Table 2. Indicators of environmental impacts, aspects of resource use and waste, based on EPD (ITB, 2013).

\begin{tabular}{lll}
\hline \multicolumn{1}{c}{ Environmental impacts } & \multicolumn{1}{c}{$\begin{array}{c}\text { Environmental aspects of } \\
\text { resource use (modified) }\end{array}$} & $\begin{array}{c}\text { Environmental information of } \\
\text { waste categories }\end{array}$ \\
\hline Global warming potential & $\begin{array}{l}\text { Total use of renewable primary } \\
\text { energy (as raw mat. or energy) }\end{array}$ & Hazardous waste disposed \\
\hline $\begin{array}{l}\text { Depletion potential of the } \\
\text { stratospheric ozone layer }\end{array}$ & $\begin{array}{l}\text { Total use of non-renewable } \\
\text { primary energy (as raw mat. or } \\
\text { energy) }\end{array}$ & Non-hazardous waste disposed \\
\hline $\begin{array}{l}\text { Acidification potential of soil and } \\
\text { water) }\end{array}$ & Use of secondary material & Radioactive waste disposed \\
\hline Eutrophication potential & Use of renewable second. fuels & Components for re-use \\
\hline $\begin{array}{l}\text { Formation potential of } \\
\text { tropospheric ozone }\end{array}$ & $\begin{array}{l}\text { Use of non-renewable second. } \\
\text { fuels }\end{array}$ & Materials for recycling \\
\hline $\begin{array}{l}\text { Abiotic depletion potential (ADP- } \\
\text { elements) for non-fossil resources }\end{array}$ & Net use of fresh water & Materials for energy recovery \\
\hline $\begin{array}{l}\text { Abiotic depletion potential (ADP- } \\
\text { fossil fuels) for fossil resources }\end{array}$ & - & Exported energy \\
\hline
\end{tabular}

\section{Therefore, in the literature review process, the sources' approach to the life cycle phases was} juxtaposed to life cycle phases used in LCA and adopted for EPDs (Table 1). In this paper, the "environmentally friendly" aspects were considered only those covered by the scope of the environmental impacts, aspects of resource use, and generation of waste as defined in EPDs (Table 2) prepared according to EN 15804:2012 before its amendment in 2019 (ITB, 2013).

\subsection{The Sample}

The query was arbitratil author-specified keywords:
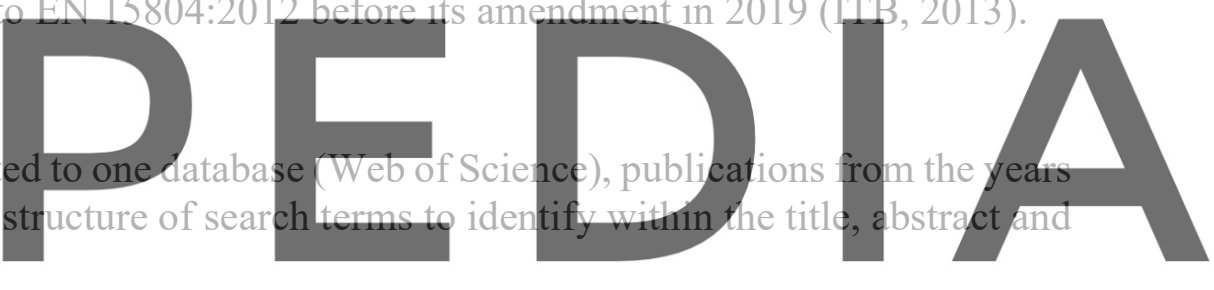

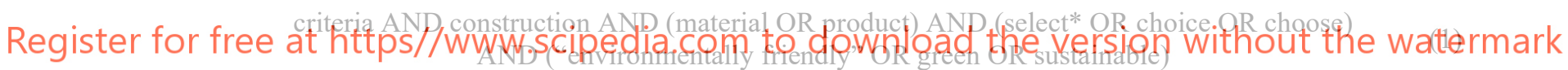

The query produced a reasonable number of 110 publications. The selection was manually refined, on the basis of content analysis, to find papers that focused explicitly on:

- analyzing criteria for selecting materials or component options or options of construction methods based on their environmental impact,

- presenting methods or tools for assessing the environmental impact of materials or components or construction methods to justify their selection or ranking,

- individual presentations of selection/ranking problems as above (case studies),

- arguments for "green" properties" of new materials if juxtaposed with "traditional" materials.

For this reason, a considerable number of papers were excluded as proposals of new certification systems for whole buildings, general-purpose multicriteria methods where "green" features served only as examples of possible criteria, and papers focused on ecology (impact of built structures on particular species). One paper was excluded for not being available in English, and four proved unreachable (no access to full text). Therefore, the final sample comprised only 43 publications. 


\subsection{The Method}

The sample of papers was analyzed in terms of aspects of sustainability covered by the analysis, scope of life cycle stages, sources of input, and mathematical methods used for selecting the best option (if applicable).

\section{Results and Discussion}

\subsection{Topics of the Sample}

The papers of the sample were classified into four groups according to their research problem (some paper dealt with more than one):

- designing environmentally-friendly materials (9 papers),

- selecting a set of sustainability criteria for comparing construction products or components of built structures ( 7 papers),

assessing the sustainability of alternative solutions (materials, material supply chains, component design) (33 papers), optimizing construction components (2 papers).

\subsection{Type and Number of Environmental Criteria}

Nine papers from the sample focused on introducing environmental criteria into the design of materials themselves (Table 3). One of them (Imron et al., 2017a) argued for eco-friendly properties of a new dry early stage of research, arbitrarily selected envit. and thus redueing the cons ywall in
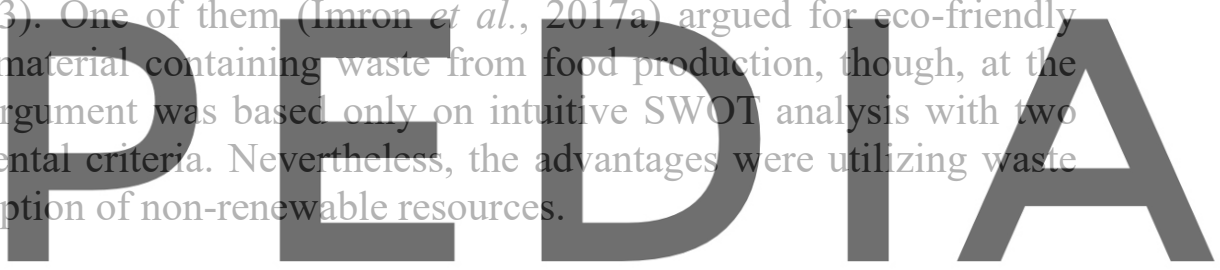

Table 3. Papers devoted to material design (selecting components for a mix).

Register fonfuree at https//wads dipediaccom to dowaloadothe versiontdiathout thetwatermark

\begin{tabular}{|c|c|c|c|c|c|c|c|}
\hline (Imron et al., 2017b) & En & A & Arbitrary & - & 2 & - & SWOT \\
\hline (Ahmed et al., 2019) & $\begin{array}{l}\text { T,Ec, } \\
\text { En, S }\end{array}$ & $\begin{array}{l}\text { not } \\
\text { explicit }\end{array}$ & $\begin{array}{l}\text { Team of } \\
\text { experts }\end{array}$ & $\begin{array}{l}\text { Team of experts, } \\
\text { AHP; sensitivity } \\
\text { analysis }\end{array}$ & 6 & $\begin{array}{l}\text { T. of experts } \\
\text { (pairwise comp.) }\end{array}$ & $\begin{array}{l}\text { AHP, } \\
\text { TOPSIS }\end{array}$ \\
\hline (Falqi et al., 2019) & $\begin{array}{l}\text { T,Ec, } \\
\text { En, S }\end{array}$ & $\begin{array}{l}\text { not } \\
\text { explicit }\end{array}$ & Arbitrary & $\begin{array}{l}\text { M. experts, } \\
\text { arithmetic mean of } \\
\text { fuzzy ratings }\end{array}$ & 5 & $\begin{array}{l}\text { M. experts, } \\
\text { arithmetic mean } \\
\text { of fuzzy ratings }\end{array}$ & $\begin{array}{l}\text { fuzzy } \\
\text { TOPSIS }\end{array}$ \\
\hline (Kurda et al., 2019) & $\begin{array}{l}\text { T, Ec, } \\
\text { En }\end{array}$ & A1-A3 & $\begin{array}{l}\text { Arbitrary } \\
\text { (LCA) }\end{array}$ & $\begin{array}{l}\text { Arbitrary (no. of } \\
\text { scenarios) }\end{array}$ & 2 & $\begin{array}{l}\text { Databases \& } \\
\text { calculations }\end{array}$ & SAW \\
\hline (Rashid et al., 2018) & $\mathrm{T}, \mathrm{En}$ & A1-A3 & Arbitrary & Arbitrary & 2 & $\begin{array}{l}\text { Databases \& } \\
\text { calculations }\end{array}$ & $\begin{array}{l}\text { AHP, } \\
\text { TOPSIS }\end{array}$ \\
\hline (Reddy et al., 2020) & $\begin{array}{l}\text { T, Ec, } \\
\text { En, S }\end{array}$ & $\begin{array}{l}\text { not } \\
\text { explicit }\end{array}$ & Arbitrary & Not applicable & 1 & $\begin{array}{l}\text { Databases \& } \\
\text { calculations }\end{array}$ & PSI \\
\hline (Reddy et al., 2019b) & $\begin{array}{l}\text { Ec, En, } \\
S\end{array}$ & A-D & Arbitrary & $\begin{array}{l}\text { M. experts, } \\
\text { relative } \\
\text { importance index }\end{array}$ & 5 & M. experts & AHP \\
\hline (Reddy et al., 2019a) & $\begin{array}{l}\text { Ec, En, } \\
\text { S }\end{array}$ & A-D & Arbitrary & M. experts, AHP & 5 & M. experts & AHP \\
\hline $\begin{array}{l}\text { (Suarez Silgado et al., } \\
\text { 2018) }\end{array}$ & Ec, En & A1-A3 & LCA & $\begin{array}{l}\text { Arbitrary; } \\
\text { sensitivity analysis }\end{array}$ & 11 & $\begin{array}{l}\text { Databases \& } \\
\text { calculations }\end{array}$ & VIKOR \\
\hline
\end{tabular}


The remaining papers from this group presented a multicriteria selection of components (such as recycled aggregates or supplementary cementing materials made of waste) for concrete or asphalt mixes. All authors proposed a combined index to select the best mix out of the set of samples. However, the types of criteria incorporated in the indices were an individual selection of environmental (En), economic (Ec), social (S), and, in some cases, technological (T) properties of the mix and the hardened material. The number of environmental sub-criteria varied from one to eleven; the most common among them were: energy use and global warming potential. The authors did not agree on the life cycle stages included in the assessment.

In four papers out of seven, the authors decided to use criteria originating from some established LCA methodologies and calculate their values according to relevant life cycle inventory databases. Two papers (Kurda et al., 2019; Suarez Silgado et al., 2018) came from Europe, where such databases are available. One paper originated from Pakistan (Rashid et al., 2018) and based on data found in the literature. The last one was from India (Reddy et al., 2020); its only environmental criterion was service life estimate. Other authors resorted to expert ratings of criteria values expressed in some form of Likert scales or as pairwise comparisons.

Seven papers from the sample focused primarily on selecting sustainability criteria for comparing construction products or components of built structures. Khoshnava et al. (2018) observed that, in practice, the choice of "green" criteria was done arbitrarily by the decisionmakers. Therefore, the authors undertook a literature review and a broad survey among construction professionals to decide on a general-purpose set of criteria and their relative importance, as perceivect of 23 criteria (out of 1 he Attia (2019) conducted and their relative importance specifically for buildings. (Herda et al.
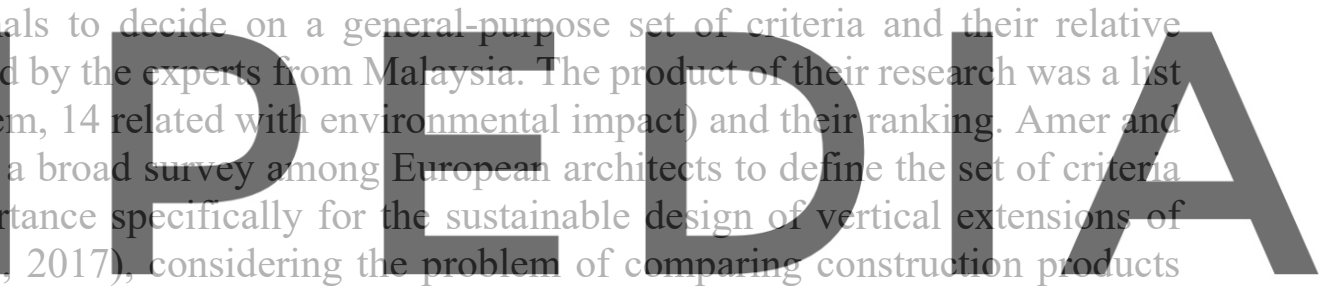

and switching to sustainable construction in Kenya, pointed to the lack of reliable databases of

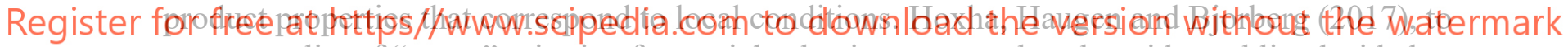
propose a list of "green" criteria of material selection to appeal to the wider public, decided to investigate into the understanding of sustainability in Kosovo by means of a survey among nonprofessionals. Rashdan and Ashour (2018) reviewed the literature to define a list of aspects worth consideration in sustainability assessment of interior design products. Li et al. (2019) reviewed literature on factors incorporated into LCA and life cycle costing (LCC) related with assessing benefits of using solid waste for road pavement, finding that there is still no agreement on what properties and impacts should be included in such analyses. (Ishak et al., 2017), to measure the self-assessed level of compliance of Malaysian construction products manufacturers with the rules of "green" production, compiled a list of as many as 33 environmental criteria based on the literature.

\section{Summary and Conclusions}

Judging by the analyzed sample of papers, there exists no agreed set of environmental criteria for comparing sustainability of alternative construction products, components and construction methods (Figure 1). 


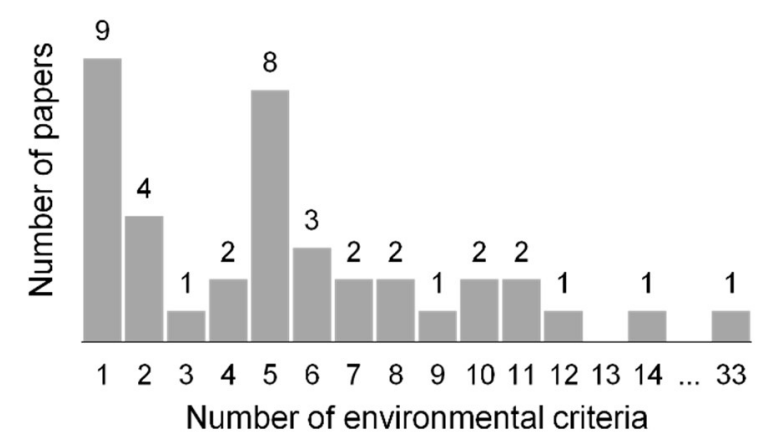

Figure 1. Frequency of selecting a particular number of criteria in the sample of papers.

Interestingly, even in the case of similar problems, the numbers and the type of criteria differed significantly. For instance, Potkany, Gejdos and Debnar (2018), Svajlenka and Kozlovska (2018), and Hassan and Johansson (2018) compared options of building frames basing on a set of sustainability measures without combining them into one index. They all did it within "cradle to gate" boundaries. Respectively, they used: six criteria known from EPD's (Table 1): primary energy input for production (PEI), global warming potential (GWP), acidification potential (AP), eutrophication potential (EP), ozone depletion potential (ODP), and photochemical ozone creation potential (POCP), three criteria (PEI, GWP, AP), and a single criterion (GWP).

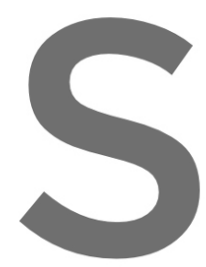

Even the authors who d

different criteria: energy

to the construction phas

most authors identified the criteria in the cou

experts to refine the list to suit a particular decisior

from particular LCA methodologies.
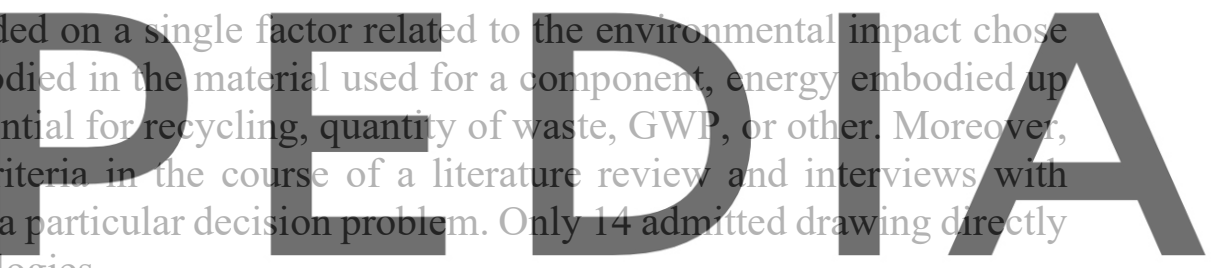

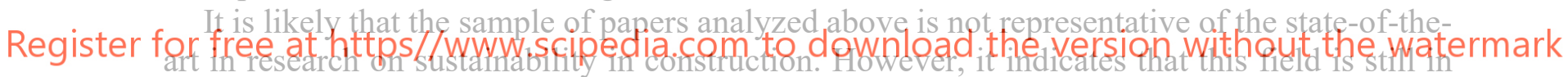
the stage of development.

\section{Acknowledgements}

The work was funded by the Polish Ministry of Science and Higher Education ILT 63. The authors gratefully acknowledge the support.

\section{ORCID}

Robert Bucoń: https://orcid.org/0000-0002-9397-639X

Agata Czarnigowska: https://orcid.org/0000-0003-3715-3521

\section{References}

Ahmed, M., Qureshi, M. N., Mallick, J. and Ben Kahla, N. (2019). Selection of Sustainable Supplementary Concrete Materials Using OSM-AHP-TOPSIS Approach. Advances in Materials Science and Engineering, 2019. doi: $10.1155 / 2019 / 2850480$

Allacker, K., Mathieux, F., Pennington, D. and Pant, R. (2017). The search for an appropriate end-of-life formula for the purpose of the European Commission Environmental Footprint initiative. International Journal of Life Cycle Assessment, 22(9), 1441-1458. doi: 10.1007/s11367-016-1244-0

Amer, M. and Attia, S. (2019). Identification of sustainable criteria for decision-making on roof stacking 
construction method. Sustainable Cities and Society, 47(June 2018), 101456. doi: 10.1016/j.scs.2019.101456

Bak, J., Radziszewska-Zielina, E. and Zielina, M. (2019). Analysis of the Spatial Structure of Green Building in the Aspect of Selected Environmental Issues on the Example of the City of Cracow (Poland). IOP Conference Series: Materials Science and Engineering, 603(4). doi: 10.1088/1757-899X/603/4/042099

Bucoń, R. (2019). Model supporting decisions on renovation and modernization of public utility buildings. Open Engineering, 9(1), 178-185. doi: 10.1515/eng-2019-0022

D’Amato, D., Droste, N., Winkler, K. J. and Toppinen, A. (2019). Thinking green, circular or bio: Eliciting researchers' perspectives on a sustainable economy with Q method. Journal of Cleaner Production, 230, 460476. doi: 10.1016/J.JCLEPRO.2019.05.099

Doan, D. T., Ghaffarianhoseini, A., Naismith, N., Zhang, T., Ghaffarianhoseini, A. and Tookey, J. (2017). A critical comparison of green building rating systems. Building and Environment, 123, 243-260. doi: 10.1016/J.BUILDENV.2017.07.007

European Commission. (2013). Recommendation 2013/179/EU on the use of common methods to measure and communicate the life cycle environmental performance of products and organisations. In Official Journal of European Union (Issue L 124). doi: doi:10.3000/19770677.L_2013.124.eng

Falqi, I. I., Ahmed, M. and Mallick, J. (2019). Siliceous Concrete Materials Management for Sustainability Using Fuzzy-TOPSIS Approach. Applied Sciences, 9(17). doi: 10.3390/app9173457

Galatola, M. and Pant, R. (2014). Reply to the editorial "product environmental footprint - breakthrough or breakdown for policy implementation of life cycle assessment?" Written by Prof. Finkbeiner (Int J Life Cycle Assess 19(2):266-271). International Journal of Life Cycle Assessment, 19(6), 1356-1360. doi: 10.1007/s11367-014-0740-3

Goh, C. S., Chong, H.-Y., Jack, L. and Mohd Faris, A. F. (2020). Revisiting triple bottom line within the context of sustainable construction: A systematic review. Journal of Cleaner Production, 252, 119884. doi: 10.1016/J.JCLEPRO.2019.119884

Goldstein, B., Birkved, M., Quitzau, M.-B. and Hauschild, M. (2013). Quantification of urban metabolism through coupling with the life cycle asses: Research Letters, 8(3),

Häfliger, I.-F. F., John, V environmental impact Cleaner Production, 156,805-8

Hasik, V., Ororbia, M., Wa
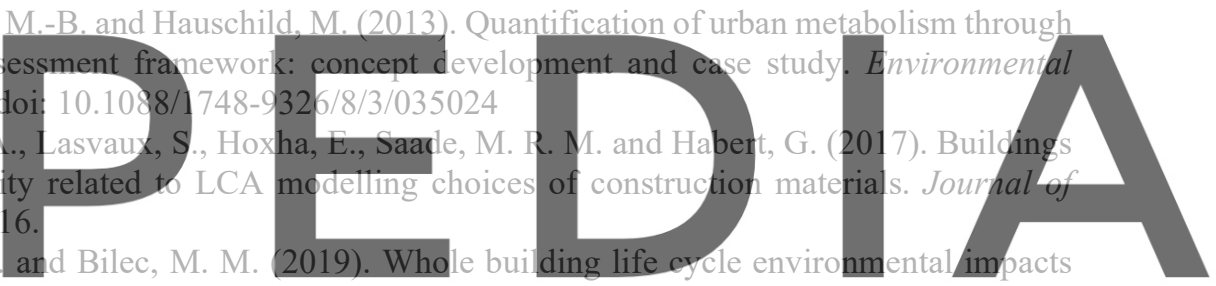
and costs: A sensitivity study of design and service decisions. Building and Environment, 163, 106316. doi:

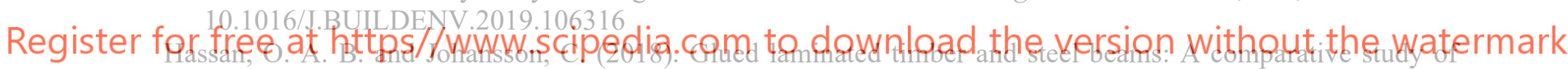
structural design, economic and environmental consequences. Journal of Engineering, Design and Technology, 16(3), 398-417. doi: 10.1108/JEDT-12-2017-0130

Herda, G., Sangori, R. and Bock, M. (2017). Low Cost, Low Carbon, but no Data: Kenya's Struggle to Develop the Availability of Performance Data for Building Products. Procedia Environmental Sciences, 38, $452-460$. doi: 10.1016/j.proenv.2017.03.136

Hoxha, V., Haugen, T. and Bjorberg, S. (2017). Measuring perception about sustainability of building materials in Kosovo. Facilities, 35(7-8), 436-461. doi: 10.1108/F-04-2016-0040

Imron, M. A., Ahkam, D. N. I. and Hidayat, A. W. (2017a). DECO FRECASE (drywall eco-friendly from eggshell and cane bagasse) as an innovation of eco-friendly interior construction. IOP Conference Series: Materials Science and Engineering, 282(1). doi: 10.1088/1757-899X/282/1/012009

Imron, M. A., Ahkam, D. N. I. and Hidayat, A. W. (2017b). DECO FRECASE (drywall eco-friendly from eggshell and cane bagasse) as an innovation of eco-friendly interior construction. IOP Conference Series: Materials Science and Engineering, 282(1). doi: 10.1088/1757-899X/282/1/012009

Ishak, N. I., Kamal, E. M. and Yusof, N. (2017). The Green Manufacturer's Compliance With Green Criteria Throughout the Life Cycle of Building Material. SAGE Open, 7(3). doi: 10.1177/2158244017725446

ITB. (2013). LCA modules and indicators (Issue Vii). https://www.itb.pl/epd.html

Jeong, J. S. and Ramirez-Gomez, A. (2018). Development of a web graphic model with fuzzy-decision-making Trial and Evaluation Laboratory/Multi-criteria-Spatial Decision Support System (F-DEMATEL/MC-SDSS) for sustainable planning and construction of rural housings. JOURNAL OF CLEANER PRODUCTION, 199, 584-592. doi: 10.1016/j.jclepro.2018.07.227 
Kellenberger, D. and Althaus, H.-J. (2009). Relevance of simplifications in LCA of building components. Building and Environment, 44(4), 818-825. doi: 10.1016/J.BUILDENV.2008.06.002

Khoshnava, S. M., Rostami, R., Valipour, A., Ismail, M. and Rahmat, A. R. (2018). Rank of green building material criteria based on the three pillars of sustainability using the hybrid multi criteria decision making method. Journal of Cleaner Production, 173, 82-99. doi: 10.1016/j.jclepro.2016.10.066

Komatsu, H., Rappleye, J. and Silova, I. (2019). Culture and the Independent Self: Obstacles to environmental sustainability? Anthropocene, 26, 100198. doi: 10.1016/J.ANCENE.2019.100198

Kuittinen, M. and Linkosalmi, L. (2015). Compiling environmental product declarations for wood-based construction products assessment and documentation (Issue July).

Kurda, R., de Brito, J. and Silvestre, J. D. (2019). CONCRETop - A multi-criteria decision method for concrete optimization. Environmental Impact Assesment Review, 74, 73-85. doi: 10.1016/j.eiar.2018.10.006

Li, J., Xiao, F., Zhang, L. and Amirkhanian, S. N. (2019). Life cycle assessment and life cycle cost analysis of recycled solid waste materials in highway pavement: A review. Journal of Cleaner Production, 233, 11821206. doi: 10.1016/j.jclepro.2019.06.061

Meadows, D. H., Meadows, D. L., Randers, J. and Behren, W. W. (1972). The Limits to growth: A report for the Club of Rome's project on the predicament of mankind. Universe Books.

Nematchoua, M. K., Asadi, S. and Reiter, S. (2020). A study of life cycle assessment in two old neighbourhoods in Belgium. Sustainable Cities and Society, 52, 101744. doi: 10.1016/J.SCS.2019.101744

Ortiz, O., Castells, F. and Sonnemann, G. (2009). Sustainability in the construction industry: A review of recent developments based on LCA. Construction and Building Materials, 23(1), 28-39. doi: 10.1016/J.CONBUILDMAT.2007.11.012

Park, J., Yoon, J. and Kim, K.-H. (2017). Critical review of the material criteria of building sustainability assessment tools. Sustainability (Switzerland), 9(2). doi: 10.3390/su9020186

Passer, A., Lasvaux, S., Allacker, K., De Lathauwer, D., Spirinckx, C., Wittstock, B., Kellenberger, D., Gschösser, F., Wall, J. and Wallbaum, H. (2015). Environmental product declarations entering the building sector: critical reflections based on 5 to 10 years experiende in different European countries. Intexnational Journal of Life
Cycle Assessment, 20(9), 1199-1212. doi:10.1007/s11367-015-0926-3
Confecki, M. (2014). Added value of the European Core EPD. Proceedings of the World Sustainable Building
Conf, 1-7.

Rashdan, W. and Ashour, A. F. (2018). Criteria for sustainable interir design solutions. In J. Brebbia, CA and

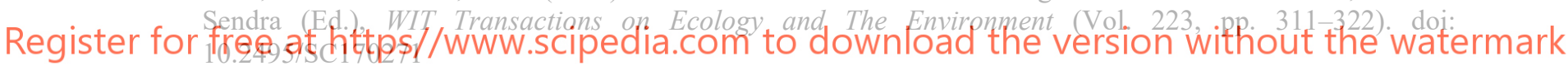

Rashid, K., Hameed, R., Ahmad, H. A., Razzaq, A., Ahmad, M. and Mahmood, A. (2018). Analytical framework for value added utilization of glass waste in concrete: Mechanical and environmental performance. Waste Management, 79, 312-323. doi: 10.1016/j.wasman.2018.07.052

Reddy, A. S., Kumar, P. R. and Raj, P. A. (2019a). Developing a Material Sustainable Performance Score (MSPS) to select an alternative Cementitious Material. Cement, Wapno, Beton, 24(1), 68+.

Reddy, A. S., Kumar, P. R. and Raj, P. A. (2019b). Preference based multi-criteria framework for developing a Sustainable Material Performance Index (SMPI). International Journal of Sustainable Engineering, 12(6), 390-403. doi: 10.1080/19397038.2019.1581853

Reddy, A. S., Kumar, P. R. and Raj, P. A. (2020). Development of Sustainable Performance Index (SPI) for SelfCompacting Concretes. Journal of Building Engineering, 27. doi: 10.1016/j.jobe.2019.100974

Suarez Silgado, S., Calderon Valdiviezo, L., Gasso Domingo, S. and Roca, X. (2018). Multi-criteria decision analysis to assess the environmental and economic performance of using recycled gypsum cement and recycled aggregate to produce concrete: The case of Catalonia (Spain). Resources, Conservation \& Recycling, 133, 120 131. doi: 10.1016/j.resconrec.2017.11.023

Svajlenka, J. and Kozlovska, M. (2018). Houses Based on Wood as an Ecological and Sustainable Housing Alternative-Case Study. Sustainability (Switzerland), 10(5). doi: 10.3390/su10051502

Turner, G. M. (2008). A comparison of The Limits to Growth with 30 years of reality. Global Environmental Change, 18(3), 397-411. doi: 10.1016/J.GLOENVCHA.2008.05.001 